\title{
A Atuação do DASP na Mensagem ao Congresso Nacional do Presidente Emílio G. Médici (1o de março de 1974) - Dimensionamento de um Desempenho Satisfatório
}

O DASP desencadeou, em função dos objetivos do Decreto-Lei . $^{\circ} 200 / 67$, e de acordo com as diretrizes da Lei n. 5.645 , de 1970, um vasto elenco de providências estreitamente correlacionadas, que lograram assegurar, simultaneamente com a irreversibilidade do novo Plano de Classificação de Cargos do Serviço Civil da União, extraordinárias perspectivas no concernente ao treinamento abrangente e avançado dos recursos humanos de que o Brasil carece para o seu pleno desenvolvimento.

Referimo-nos, expressamente, ao Centro de Aperfeiçoamento (CENDAP) - cuja construção prossegue, em ritmo acelerado, e vem emergindo, aos poucos, com as dimensöes de um empreendimento decisivo, em face das suas funçōes modernizantes no roteiro da renovaçãa, transformação e perene aprimoramento da Administração Federal.

São, estas, conquistas auspiciosas de toda a Nação Brasileira a respeito das quais a Revista do Serviço Público tem divulgado pesquisas e trabalhos de valor incontestável, inclusive publicando, através de suas excelentes traduções, contribuiçōes estrangeiras da melhor categoria, visando levar ao conhecimento das autoridades, dos técnicos, dos estudiosos $\theta$ dos servidores públicos categorizados as mais recentes, úteis e atualizadas informações de natureza científica e tecnológica no campo das Ciências Sociais e da Administração, em par-
ticular.

A própria Revista do Serviço Público, - em virtude das radicais transformaçöes por que vem passando nestes últimos anos, do ponto de vista de sua programação editorial e aperfeiçoamento grafotécnico, deve ser considerada como uma daquelas mencionadas conquistas auspiciosas, além de outros motivos, pelo fato de brevemente ser incorporada ao Centro de Aperfeiçoamento, na categoria de uma de suas unidades estruturais, incumbida, não somente da divulgação oficial dos trabalhos do DASP e do CENDAP, como de um complexo de atribuiçōes igualmente importantes, no âmbito da pesquisa, das traduçốes de estudos alienígenas, do ensino, do intercâmbio cultural e da realização dos seus tradicionais Concursos de Monografias sobre temas de interesse nacional.

A Política de Pessoal deflagrada pelo DASP, - ou seja, a captação, mobilização, utilização, aperfeiçoamento e profissio-

R. Serv. públ., Brasílla, 109 (1) Jan./mar. 1974 
nalização dos recursos humanos indispensáveis ao desenvolvimento nacional, - fol incluída e enfatizada nas Metas e Bases para a Ação do Governo, como um dos "objetivos prioritários da ação governamental na esfera administrativa".

Não seria oportuno enumerar e esmiuçar, nos limites de um comentário necessariamente sucinto, a procissão dos fenômenos negativos, assaz conhecidos dos analistas da Administração de Pessoal, - obstaculizando os esforços de racionalização que se têm caracterizado como a preocupação absorvente do DASP no desempenho de funções de pesquisas e equacionamento de soluções modernizantes, a par das suas responsabilidades legais como laboratório central da normatividade Jurídica $\theta$ técnica indispensável à coordenação, supervisão $\theta$ controle dos assuntos concernentes à Administração do Pessoal Civil da União, atividade que o-DASP vem desenvolvendo sob o comando direto do Chefe da Nação.

Aí estão, numa seqüência lógica de encadeamento e adequação aos impositivos da Administração Federal, os instru. mentos legais decisivos à exeqüibilidade da Nova Classificação de Cargos e do CENDAP, - preliminares básicas e fundamento de uma autêntica revoluçăo no Serviço Público brasileiro.

A Revista do Serviço Público não poderia deixar de registrar, nesta oportunidade, como um documento histórico consagrador dos esforços do DASP, os conceitos emitidos pelo Presidente EMÍLIO G. MÉDICI em sua Mensagem ao Congresso Nacional, a $10^{\circ}$ de março do corrente ano de 1974. Justifica-se a transcrição, embora concisamente, das palavras do Chefe da Nação que dimensionaram e elucidam, de maneira insofismável, o desempenho do DASP no cenário da Administração brasileira.

\section{Assim falou o Presidente EMILIO G. MÉDICI :}

\section{DEPARTAMENTO ADMINISTRATIVO DO PESSOAL CIVIL - DASP}

$\mathrm{Na}$ área da Administração de Pessoal, o Governo deflagrou marcante e profunda reformulação, desenvolvendo inédita estratégla de recursos humanos. 
Iniciou-se esse programa de ação com a reforma organizacional do Departamento Administrativo do Pessoal Civil DASP, dando-lhe estrutura funcional e maleável, com o propósito de racionalizar as suas atividades e capacitá-lo a participar efetivamente da nova política de pessoal.

Supletivamente, institucionalizou-se o Sistema de Pessoal Civil, disciplinando o complexo de atividades e órgãos relacionados com a problemática de recursos humanos no Serviço Público Civil e com a constituição da Auditoria de Pessoal, já em funcionamento experimental.

Prosseguiram a elaboração $\mathrm{e}$ aprovação dos documentos relativos à classificação e retribuição de cargos e empregos dos órgãos da Administração Direta e das Autarquias : a Lei n. 5.645 , de 10 de dezembro de 1970 , que estabelecera as suas diretrizes, bem como as normas complementares que vivificaram os sistemas ali instituídos; o estabelecimento de critérios técnicos e uniformes de avaliação de cargos e empregos, que orientaram a fixação e a aprovaçăo legislativa dos novos níveis de vencimentos dos grupos de categorias funcionais; a estruturação dos Grupos "Direção e Assessoramento Superiores", "Pesquisa Científica e Tecnológica", "Diplomacia", "Serviços Jurídicos", "Polícla Federal", "Tributação, Arrecadação o Fiscalização", "Artesanato", "Serviços Auxillares, "Outras Atividades de Nível Superior", "Outras Atividades de Nivel Médio" e "Transporte Oficial e Portaria", bem como a aprovação das especificações de classes das respectivas Categorias Funcionais; o início da aplicação dos novos planos, abrangendo os Grupos "Direção e Assessoramento Superiores", "Diplomacia", "Serviços Auxiliares" e "Transporte Oficial é Portaria".

Completou-se, assim, a montagem das novas sistemáticas de classificação e retribuição de cargos e empregos, restando, apenas, a sua implementação, situada na área de competência dos órgăos setoriais e seccionais de pessoal, dependente de recursos orçamentárlos para custear as correspondentes despesas.

Não descurou o Governo das tarefas relacionadas com a normalização do plano de classificação em fase de extinção, erradicando os casos individuais de readaptação e redistribuindo servidores desnecessários aos órgãos a que pertenciam. 
Constituem fases operacionais relevantes o planejamento - a implantação gradativa do Cadastro Geral de Pessoal, que irá processando eletronicamente os dados ou registros inerentes aos cargos e seus ocupantes - instrumento essencial ao controle dos quadros de pessoal e ao levantamento e atualização dos respectivos custos.

As atividades de Recrutamento e Seleção vêm participando eficazmente, mediante fixação do processo seletivo adequado, na transposição ou transformação dos cargos ocupados para a nova sistemática. Nessa mesma área, vem constituindo constante preocupação a pesquisa e o estabelecimento de modernas metodologias a serem utilizadas na revitalização dos atuais quadros de pessoal.

No âmbito da Legislação de Pessoal, realizaram-se pesquisas e estudos com vistas ao novo Estatuto dos Servidores Civis, elaborado sob as mais atualizadas técnicas legislativas, fixando apenas os princípios substantivos. Enquanto isso, as FORMULAÇŌES disseminam normas destinadas a orientar os órgãos operacionais, cristalizando a jurisprudência administrativa.

No campo do Treinamento do funcionalismo em geral, instrumentaram-se os órgãos componentes do Sistema de Pessoal Civil para a iniciação do processo contínuo, permanente, de atualização de conhecimentos e aquisição de novas técnicas de trabalho.

Programa específico, constituído do recrutamento, seleção, aperfeiçoamento e administração, atinentes aos cargos integrantes do Grupo - Direção e Assessoramento Superiores, mereceu cuidados especiais do Governo, que está empenhado na já iniciada construção, bem como no funcionamento, em Brasília, do Centro de Aperfeiçoamento - órgão autônomo vinculado ao DASP, carreando recursos na ordem de Cr\$ ...... $21.300 .000,00$.

Concretizou-se, desse modo, a promessa do Governo de adotar as medidas cabiveis para dignificar a funçäo pública e profissionalizar seus funcionários, simultaneamente com a premência de dotar a Administraçắo de recursos humanos altamente capacitados, indispensáveis à realização de suas relevantes atribuições. 